\title{
Human Resources Management Practices, Psychological Contract Fulfillment and Organizational Commitment in Deluxe Hotels in Jeddah, Saudi Arabia
}

\author{
Mansour A. Al-miman ${ }^{1}, \mathrm{PhD}$ \\ ${ }^{1}$ Department of Management Technology, College of Technology, Jeddah, Technical and Vocational Training \\ Corporation, Saudi Arabia, Fax:00966-2-6378376, PO Box 17608, Jeddah 21494,Kingdom of Saudi Arabia \\ Correspondence: Mansour A. Al-miman, PhD, Department of Management Technology, College of Technology, \\ Jeddah, Technical and Vocational Training Corporation, Saudi Arabia, Fax:00966-2-6378376, PO Box 17608, \\ Jeddah 21494,Kingdom of Saudi Arabia
}

Received: April 28, 2017

Accepted: November 14, 2017

Online Published: November 27, 2017

doi:10.5539/ijps.v9n4p94

URL: http://doi.org/10.5539/ijps.v9n4p94

\begin{abstract}
This paper study the relationship of the effectiveness of the human resources management practices of the hotels employees in the western region (Jeddah City) of Saudi Arabia with respect to their Psychological contract fulfilment (PCFul) and Organizational Commitment (OC). Data was collected from 36 hotels. Using the employees' responses, the study indicated that Human Resources practices influenced employees' perceived Psychological contract fulfilment and their Organizational Commitment, where Human Resources Management (HRM) practices are positively related to Psychological contract fulfilment and OC. The study examined whether employees consider (HRM) practices an important tool while developing psychological contracts, and presented the prospective role of the Human Resources for Developmental Purposes to foster change in the hotel industry in Saudi Arabia.
\end{abstract}

Keywords: Psychological Contracts Fulfilment, Organizational Commitment, Human Resources Management, Hotel Management, Saudi Arabia

\section{Introduction}

Although HRM practices have solid influence on employee adherence, the relationship between Organizational Commitment (OC) and HRM practices have been studied by very few researchers (Arthur, 1994; Chang 2005; Meyer \& Smith, 2000; Ogilvie, 1986). Recently, there has been significant debate about Human Resource Management (HRM) as a distinguishing method intended to gain employee assurance to institutional aims (McGunnigle \& Jameson, 2000). Therefore, by comprising varied HRM practices such as preparation, reward, welfares, gratuities, sharing, progression chances and job safety, the association inclines to improve employee relations through its assurance method (Arthur, 1994; Chang, 2005; Kinicki et al., 1992; Macduffie, 1995). An institution also articulates its assurance to the employees through its human resources management practices (Chang, 2005). To study the employee-employer interchange, researchers have gradually, but not completely, accepted two vital agendas: apparent administrative provision and psychological agreements . psychological agreements is defined as an employee's conviction concerning the expressions and circumstances of an interchange of association with their institution (Rousseau, 1989) such as (1) salaries depend on time on work, type or act (Coyle-Shapiro \& Conway, 2005), and (2) reward, preparation etc in interchange for faithfulness, act etc. Therefore, the content of psychological agreements may contain any point that might be swapped between the association and the employee (e.g., payment, preparation, provision, in interchange for faithfulness, act) (Coyle-Shapiro \& Conway, 2005). psychological agreements research has sightsaw the employer-employee interchange of affiliation by examining the penalties of apparent agreement fulfilment or breach on employee outlooks and performance (Coyle-Shapiro \& Conway, 2005). Human resources management practices are reffered to as one of the serious issues touching psychological agreement (Guzzo \& Noonan, 1994; Rousseau \& Greller, 1994). 
The aim of this article is to evaluate human resources management practices and its impact on employees' Psychological contract fulfilment (PCFul) and Organizational Commitment (OC) in the western region hotels in Saudi Arabia in order to enhance the developmental role of human resources management practices.

\section{Human Resource Management Practices, Psychological Contracts and Organizational Commitment}

A positive association between employees' organizational commitment and apparent agreement fulfilment have been described by previous research (Coyle-Shapiro \& Kessler, 2000; Pathak et al., 2005), while reduced organizational commitment caused an apparent agreement breach (Guzzo \& Noonan, 1994). Human resources practices are considered by many writers as a communication channel between employees and employer and may be inferred inversely by specific employees, and those decisions of the degree of one's psychological agreement is being satisfied can effect their commitment to the association and their intents to leave. Human resources management practices are seen to have a vital role as message transmitters, determining paragraphs of the emotional contracts. Thus, a key function of human resources management practices is to stand-in a suitable psychological agreement (Rousseau \& Greller, 1994), and employee's psychological agreement with their employer may be affected by explanations of their employer's human resources management practices.

Kinicki et al. (1992) suggested that employee insights of an organization's commitment to human resource efforts is affected by an organization's real human resources management programs, which in turn affect employees' work attitude. An employee's relationship with an organization is shaped by HRM actions such as recruiting, appraising performance, training and benefits administration through which employees come to understand the terms of their employment (Rousseau \& Greller, 1994).

The hospitality industry has been traditionally characterized by low job morale and high turnover (Deery \& Shaw, 1999; LaLopa, 1997).

A framework that was planned to measure three different sorts of organizational commitment was developed: (a) Affecting assurance which discusses the employees' involvement in the organization and their emotional attachment and identification. The employees who stay with the organization are those with a strong affecting commitment because they decided to do that. (b) Maintenance assurance means the employees' valuation if the costs of staying in the institution are less than the costs of leaving it. Employees who notice that the costs of staying in the organization are less than the costs of leaving stay because they can't leave. (c) Normative assurance means the employees feel that they are obliged to work in the institution. Some employees stay with the institution although they are with high levels of normative assurance because they feel they ought to stay.

the role that particular facets of work fulfillment serve as interpreters of organizational commitment type has been examined by previous studies (Gaertner, 1999; Jernigan et al., 2002).

Harris \& Mongiello, 2001). Any dissatisfaction with the workplace is likely to manifest in resistance to management and lower levels of customer service (Townsend, 2004). Indeed, research has traced the relationship between service industry employees that are satisfied with their jobs and a satisfied consumer base (e.g., Namasivayam, 2005). Employees with high motivation to work can respond strongly to clients' needs and offer a high level of satisfaction among clients through delivering customer services and superior quality products (Xenikou \& Simosi, 2006; Wilkins et al., 2007). Lau and Chong's (2002) study claims that the managers who are very loyal to the institution definitely will have job satisfaction. Kim et al. (2005) said that it is not possible to associate the intension to leave the institution with institutional.

HRM Practices and Organizational Commitment

Human resource management practices and strategies have been recommended as prompting reasons to rise organizational commitment between workers (Meyer \& Smith, 2000). Grounded on social interchange theory, Tansky and Cohen, (2001) proposed that when the workers have a sense that the organization is interested in their wrights and their needs, then their insights of human resource management practices reveal a sense of mutuality and the level of the organization's commitment to the employees. Actually, organizational commitment was created to have a confident association with working out (Bartlett, 2001), wage ranks, performance-reward possibilities, elevation and returns distribution (Coyle-Shapiro et al., 2002). The effect of HRM practices have been confirmed by previous research on employee outlooks and firm performance. The productivity of establishments with "assurance" human resource systems, highlighting the progress of workers' assurance, is higher compared with lower employee income and lower scrap rates (Batt, 2002; Huselid, 1995; Pathak et al., 2005; Chang, 2005). Employment and choice, preparation and progress, identical employment chances, along with good and safe working circumstances were included from Edgar and Geare's study (2005), as these practices had an important positive association with organizational commitment. Performance 
assessment efficiency was involved in Chang's (2005) study of the effect of employees' general insight about the organization's HRM practices on organizational commitment.

In USA a study was conducted by Woods et al. (1998) on 389 hotel general managers. Their study increases the threat that performance assessment seemed as a rare evaluation joint with a lack of any feedback period, seems to be a weak human-resources practice--particularly for directors who wish to use the evaluation to start employee-development strategies. Performance assessment, which is seen as making an significant influence to actual human resource management, is strictly connected to organizational performance (Erdogan, 2002), When employees trust their managers support them, the result is job satisfaction, commitment to the organization and better performance (Eisenberger et al., 2002).

Saudi Arabia hotels are considered multicultural work forces; the percentage of expatriates is still high with the nationalization of hotel jobs under 10\% (Saudi Chambers \& Saudi Tourism Information and Research Centre, 2009). Previous research indicated that human resources management practices and the insights of the employees influence organizational commitment (Chang, 2005; Kinicki et al., 1992). We can refer to the perceptions of the employees of an organization's commitment to them as "perceived organizational support" (Eisenberger et al., 1986), where HRM practices are claimed to have a significant and positive impact on organizational performance (Ramsay et al., 2000; Wood, 1999).

\subsection{Research Purpose}

This article aimed to investigate the hotel employees' perceptions of HRM practices in the western region hotels in Saudi Arabia. This study provided a lens to assess HRM practices and its impact on employees' job commitment for the purpose of enhancing the developmental role of HRM practices. The key purpose of this research was to investigate three relationships. First, the research proposed to investigate the impact of HRM practices on PC fulfilment, followed by the impact of PC fulfilment on OC and HRM practices on OC. Because of the studies' limitations relating to the influence of HRM practices on PC fulfilment in hotels, followed by the influence of PC fulfilment on $\mathrm{OC}$, there is a gap in the research literature formed by the lack of a contextually-relevant study focused on the HRM practices of hotels in Saudi Arabia. Addressing this research gap is important because HRM practices may provide a behavioral model, which helps senior managers to focus on practicing HRM practices to manage intense market competition (Boerner et al., 2007; Xenikou \& Simosi, 2006).

\subsection{Hypothesis of the Research}

These three hypotheses were proposed:

Hypothesis 1: Human Resources Mnanagement(HRM) practices will be confidently linked to Psychological Contracts (PC) Fulfilment.

Hypothesis 2: Psychological Contracts (PC) Fulfilment will be confidently linked to Organizational Commitment (OC).

Hypothesis 3: Human Resources Mnanagement (HRM) practices will be confidently linked to Organizational Commitment(OC).

\subsection{Study Limitations}

Improvements in the suggested area of the methodology and the inclusion of a wider sample and variables would significantly enhance the generalisability of the results. A future study could utilise a larger sample in Saudi Arabia and extend the sampling process beyond Saudi Arabia to include all Arab Gulf Countries. Another limitation is that the employees in the sample were drawn from Front Office and Food and Beverage. As such, future studies could include more departments and higher supervisory and managerial levels. Employees' perceptions may not be accurate, resulting in a second limitation. The self-report format of the questionnaire poses the problem of dishonesty in reporting attitude. The surveys were completed in the winter months, a moderately high season for tourism in Saudi Arabia, with low stress levels and low workloads for subordinates. Further investigation of additional individual demographic variables factors and other organizational outcomes, to include performance indicators, quality, organizational citizenship, employee productivity, and the interaction between the variables could contribute to better interpretation and use of survey data. There is a question about the generalisability of the study findings to other hospitality organizations such as three-star hotels. Longitudinal research could help to clarify how the relationship between the study variables changes throughout various stages in the life cycle of an organization (e.g., growth, decline, mergers). 


\section{Methods}

\subsection{Sample and Data Collection}

The research was conducted during winter season in 2015. Only four- and five-star luxury hotels and resorts were selected for this study, since the complexity of managing such hotels is reportedly high (Jones, 1998). There were a total of 45 four- and five-star hotels in Jeddah in 2014. Of the total, 23 were four-star, and the remaining 22 were five-star hotels (Saudi Tourism Information and Research Centre, 2009). The 36 hotels (21 five-star and 15 four-star) were managed by different multinational hotel companies or hotel chains from different countries (United States, France, Germany, Switzerland and Saudi Arabia). A total of 23 general managers in four-star hotels and 22 general managers in five-star hotels were reached for a total sample of 45 general managers. Each hotel's general manager was sent a covering letter seeking their approval to involve rooms, food and beverage department employees in the study, this is due to the fact that, jointly in four- and five-star hotels and resorts, $90 \%$ of the total revenue is generated by rooms and food and beverage departments where approximately $95 \%$ of the total human resources are employed (Powers \& Barrows, 1999). Ultimately, 36 hotels approved to participate in the study. The researcher distributed questionnaires to heads of departments through the human resource department (HRD). After answering the questionnaires, respondents returned them to the HRD in a self-sealing envelope provided by the researcher. The envelopes were then collected from the hotels. A total of 119 usable questionnaires from 36 hotels were received, giving a response rate of $63 \%$.

\subsection{Instrumentation}

The survey instrument used in this study consisted of four measures:

First: The researcher measured human resources management (HRM) practices through using a 41-item scale which consistes of statements about eight HRM practices. The researcher got these eight HRM practices from previous research that showed significant and expected effectiveness of these practices on OC and PC Fulfilment.

Second: In this study, Meyer and Allen's Three Component Model of Organizational Commitment (1997) was used to determine hotel employees' commitment level. The later version by Meyer and Allen (1997) only contained 18 items (6 items for each scale). The Organizational Commitment Questionnaire (OCQ) is a self-scoring questionnaire. Respondents were asked to indicate their agreement on a 5-point Likert scale, "1=strongly disagree, $5=$ strongly agree".

Third: Psychological contract fulfilment was measured with 12 items adapted from Coyle-Shapiro and Conway's study (2005). This measure directly accesses the extent of the fulfilment of the obligation. Respondents were asked to indicate the extent to which the item had actually been provided. Responses were on a 5-point scale, " $1=$ not at all, $5=$ very great extent".

Fourth: The ancillary questionnaire includes questions related to: age, years of experience in industry, highest educational level obtained, number of jobs quit and marital status.

\subsubsection{Instrument Standardization}

In this study, the present writer employed an Arabic version of the revised questionnaires in addition to the English version, and they were translated using a process of back translation in order to ensure the accuracy of the meanings in the instrument. The instrument was pre-tested with three individual industry contacts and three academic contacts within the hospitality field before implementation to ensure that the study was equally applicable to the situations found in a hospitality environment. The researcher presented the reliability for the questionnaires by redistributing the questionnaires to a sample of $24 \mathrm{HR}$ managers, outside that of the study but drawn from the same hotel population, two weeks after the first time. Reliability coefficient of the HRM Practices survey was found to be alpha 0.839 . Reliability coefficients for the Organizational Commitment Questionnaire (OCQ) were established for the three dimensions as follows: .79 for affective, .74 for continuance and .77 for normative. These reliability estimates seemed consistent with previous research of Allen and Meyer (1990), who reported .87 for affective, .75 for continuance, and .79 for normative. Dunham, Grube, \& Castaneda (1994) found alpha ranges of .74 to .87 for affective, .73 to .81 for continuance and .67 to .78 for normative. Cohen (1996) discovered alphas of .79 for affective, .69 for continuance and .65 for normative. The reliability of the PC scale assessed by Coyle-Shapiro and Conway's study (2005) was 0.87 . The validity of the questionnaires was assessed by 14 specialists in the field of hotel education and business administration. Based on the translation process and the reliability estimates, the Arabic-translated version of the questionnaires seemed to be a valid and reliable measure for use with this population (Jeddah Deluxe Hotels). 


\section{Results}

Data were analyzed using the Statistical Package for Social Sciences (SPSS V 17.0). Five questions were included in the survey to obtain the hotel employees demographic characteristics in Jeddah, by education level, age, length of service, marital status and number of jobs quit in five years.

Table 1. Participants' Demographic Characteristics

\begin{tabular}{llll}
\hline Characteristics & Independent Variable & Frequency & Percent \\
\hline Qualification & Intermediate School Certificate & 7 & 5.9 \\
& Secondary School Certificate & 26 & 21.8 \\
Diploma & 36 & 30.3 \\
Bachelor's & 40 & 33.6 \\
Master's or pursuing Master's & 10 & 8.4 \\
Less than 25 years & 72 & 60.5 \\
25-34 years & $35-44$ years & 37 & 31.1 \\
45 and above years & 7 & 5.9 \\
Less than one year & 3 & 2.5 \\
1-5 years & 42 & 35.3 \\
6-10 years & 55 & 46.2 \\
10 and above & 55 & 12.6 \\
Married & 15 & 5.9 \\
Number of Jobs Quit & Unmarried & 7 & 42 \\
& Once & 50 & 58 \\
& Twice & 69 & 55.5 \\
& Thrice or more & 66 & 26 \\
\hline
\end{tabular}

As Table 1 shows, of the 119 employees who completed the demographic section, for tenure with the current employer, most respondents indicated that they had worked for $(1-5)$ years $(n=55 ; 46.2 \%)$, followed by less than one year $(n=42 ; 35.3 \%)$, followed by six-ten years $(n=15 ; 12.6 \%)$ and only small number said that they worked for the institution for ten years and more $(n=7 ; 5.9 \%)$. Most of the employees who share in the study have a Bachelor's degree $(n=40 ; 33.6 \%)$, followed by a Diploma's degree $(n=36 ; 30.3 \%)$. Most of them indicated that they changed their jobs at least one time in the last five years $(n=66 ; 55.5 \%)$, twice in the last five years $(n=31 ; 26 \%)$ and the smallest number of employees reported to have changed their jobs thrice or more $(n$ $=22 ; 18.5 \%)$. Further information is displayed in Table 1 .

Data collected mirrors that the total mean score of employees' perception of HRM practices is high. (Training), which received the highest mean score of 3.932, followed by (Working Conditions $=3.912$ ), while (Rewards) was perceived as the weakest of the HRM practices with a mean score of 3.779, followed by (Equal Employment Opportunity $=3.789$ ). Further information is displayed in Table 2 . 
Table 2. Employees' Perception of HRM Practices in the Hotels

\begin{tabular}{lllll}
\hline Variables & Mean & Std. Deviation & Rank & Level \\
\hline Training & 3.932 & .8255 & 1 & High \\
Performance Appraisal & 3.911 & .7855 & 3 & High \\
Staffing & 3.823 & .7979 & 6 & High \\
Rewards & 3.779 & .9192 & 8 & High \\
Benefits & 3.892 & .8809 & 4 & High \\
Working Conditions & 3.912 & .7449 & 2 & High \\
Equal Employment Opportunity & 3.789 & .8460 & 7 & High \\
Information Sharing & 3.8571 & .7772 & 5 & High \\
\hline
\end{tabular}

The mean score for statement "My employer encourages me to extend my abilities" under the Training was the highest on the total scale with a mean score of (4.08), followed by (My working conditions here are good.) (4.03), followed by (My health has not suffered as a result of working for this organization.) under the Working Conditions (4.00), while the statement (My employer asks my opinions about how I can improve my job.) (3.66), was followed by the statement (In my company, pay raises are determined mainly by an employees' job performance). (3.68), and (Pay incentives such as bonus is an important part of the compensation strategy in this Company.) (3.68) under the Rewards followed by (My employer encourages employee participation in benefits decision making) (3.73) under the Benefits received the weakest ratings.

Table 3 contains information for the three organizational commitment scales. The mean score for employees concerning Affective Commitment was 3.52 (SD, .722). The mean score for employees concerning Normative Commitment was 3.68 (SD, .703), and for Continuance Commitment, it was 3.74 (SD, .635). The PC Fulfilment scale has a high mean score of (3.77). In measuring the degree to which psychological contracts are fulfilled and the extent to which an obligation was perceived by an employee, the mean score for the statement (Fair pay compared to staff doing similar work in other organizations) was the highest on the total scale with a mean score of (4.00), followed by (Up to date training and development) (3.92), while the following statements (Fringe benefits that are fair compared to what staff doing similar work in other organizations) received the weakest ratings (3.44), followed by (Freedom to do my job well) (3.64), (Pay increases to maintain my standard of living) (3.66) and (Fair pay for responsibilities in job) with a mean score of (3.70).

Table 3. Descriptive Statistics for Commitment Scales and PC Fulfilment

\begin{tabular}{lllll}
\hline & $\begin{array}{l}\text { Affective } \\
\text { Commitment }\end{array}$ & $\begin{array}{l}\text { Normative } \\
\text { Commitment }\end{array}$ & $\begin{array}{l}\text { Continuance } \\
\text { Commitment }\end{array}$ & PC Fulfilment \\
\hline Mean & 3.5280 & 3.6863 & 3.7465 & 3.7754 \\
Std. Dev. & .72236 & .70383 & .63589 & .96222 \\
\hline
\end{tabular}

The Pearson correlation analyses are presented in Table 4. The following summary identifies the significant associations between perceived HRM practice effectiveness, and the three organizational commitment scales.

Results revealed moderately strong correlations among the HRM practice effectiveness subscales, $r=.302$ to $r=.752$. All were statistically significant with $p<.01$. For the organizational commitment scales, there was a statistically significant correlation between affective commitment and normative commitment at $r=.494$. This finding is consistent with results from other researchers (Allen \& Meyer, 1990; Cohen, 1996). In discussing this overlap, Meyer, Allen, and Smith (1993) who contend that despite the moderately high correlations between affective commitment and normative commitment, the correlations these two scales have with other outcome variables (e.g. performance, satisfaction) are sufficiently different to warrant retaining both scales.

Additionally, it was investigated how the HRM practice effectiveness subscales correlated with the organizational commitment scales and PC. With $(p<.01)$ and $(p<.05)$, all the HRM practices subscales had positive, statistically significant correlations with affective commitment, $r=.237$ to $r=.356$, and positive, statistically significant 
correlations with normative commitment, $r=.200$ to $r=.508$. Some HRM practices subscales also had positive, statistically significant correlations: Rewards, $r=.302$; Information Sharing; and $r=.263$ with Continuance Commitment. PC Fulfillment had positive, statistically significant correlations with HRM practices subscales $r$ $=.289$ to $r=.687$. and with all organizational commitment scales $r=.264$ to $r=.436$. (See Table 4)

These findings suggest that there is a positive, although not very strong, relationship between the HRM practices and affective and normative commitment. The HRM practices are related to Continuance Commitment, this suggests that Rewards, Working Conditions; Equal Employment Opportunity; and Information Sharing, are somewhat related to how employees feel about needing to stay with the hotel. For Normative Commitment and Affective Commitment, the findings suggest that these HRM practices scales are similarly related to how employees feel about their obligation to stay with the hotel and affect how employees feel about wanting to stay with the hotel. The perceived effects of factors of HRM practices were significantly and positively related to PC Fulfillment, signify that as employees' level of their perception of the HRM practice effectiveness increased, the level of employee PC fulfilment also increased.

Table 4. Summary of the Pearson Correlation Matrix

\begin{tabular}{|c|c|c|c|c|c|c|c|c|c|c|c|c|}
\hline & $\mathbf{T}$ & PA & $\mathbf{S}$ & $\mathbf{R}$ & B & WC & EE & IS & PCFul & $\mathrm{AC}$ & $\mathrm{NC}$ & $\mathrm{CC}$ \\
\hline $\mathbf{T}$ & 1 & $.590^{* *}$ & $.317^{* *}$ & $.437^{* *}$ & $.302^{* *}$ & $.361^{* *}$ & $.415^{* *}$ & $.390^{* *}$ & $.289^{* *}$ & $.304^{* *}$ & $.293^{* *}$ & .152 \\
\hline PA & & 1 & $.473^{* *}$ & $.366^{* *}$ & $.439^{* *}$ & $.326^{* *}$ & $.379^{* *}$ & $.482^{* *}$ & $.357^{* *}$ & $.237^{* *}$ & $.200^{*}$ & .050 \\
\hline $\mathbf{S}$ & & & 1 & $.661^{* *}$ & $.614^{* *}$ & $.558^{* *}$ & $.584^{* *}$ & $.586^{* *}$ & $.456^{* *}$ & $.322^{* *}$ & $.247^{* *}$ & .145 \\
\hline $\mathbf{R}$ & & & & 1 & $.709^{* *}$ & $.573^{* *}$ & $.752^{* *}$ & $.597^{* *}$ & $.659^{* *}$ & $.352^{* *}$ & $.508^{* *}$ & $.302^{* *}$ \\
\hline B & & & & & 1 & $.630^{* *}$ & $.692^{* *}$ & $.721^{* *}$ & $.635^{* *}$ & $.318^{* *}$ & $.385^{* *}$ & $.218^{*}$ \\
\hline WC & & & & & & 1 & $.731^{* *}$ & $.627^{* *}$ & $.585^{* *}$ & $.320^{* *}$ & $.343^{* *}$ & $.234^{*}$ \\
\hline $\mathbf{E E}$ & & & & & & & 1 & $.734^{* *}$ & $.687^{* *}$ & $.270^{* *}$ & $.326^{* *}$ & $.217^{*}$ \\
\hline IS & & & & & & & & 1 & $.657^{* *}$ & $.356^{* *}$ & $.358^{* *}$ & $.263^{* *}$ \\
\hline PCFul & & & & & & & & & 1 & $.298^{* *}$ & $.436^{* *}$ & $.264^{* *}$ \\
\hline AC & & & & & & & & & & 1 & $.494^{* *}$ & $.497^{* *}$ \\
\hline $\mathrm{NC}$ & & & & & & & & & & & 1 & $.542^{* *}$ \\
\hline $\mathrm{CC}$ & & & & & & & & & & & & 1 \\
\hline
\end{tabular}

**Correlation is statistically significant with $p<.01$.

*Correlation is statistically significant with $p<.05$.

Note: $\mathrm{T}=$ Training; $\mathrm{PA}=$ Performance Appraisal; $\mathrm{S}=$ Staffing; $\mathrm{R}=$ Rewards; $\mathrm{B}=$ Benefits; $\mathrm{WC}=$ Working Conditions; $\mathrm{EE}=$ Equal Employment Opportunity; IS = Information Sharing; AC = Affective Commitment; NC = Normative Commitment; $\mathrm{CC}=$ Continuance Commitment; $\mathrm{PCFul}=$ PC Fulfilment.

Regression results based on factor scores revealed HRM practice effectiveness suggest that Training explained $(9 \%)$ of the variation in whether employees want to or do not want to stay with the hotel and (9\%) of the variation in whether employees feel obligated to or do not feel obligated to stay with the hotel and some (2\%) in whether employees need to or do not need to stay with the hotel. Rewards explained (12\%) of the variation in employees Affective Commitment and explained most of the variation (26\%) in Normative Commitment and the greatest amount of variation $(9 \%)$ in Continuance Commitment as well. Information Sharing explain the most variation (13\%) in the Affective Commitment and explained (13\%) of the variation in Normative Commitment. Benefits explained $(15 \%)$ of the variation in employees' Normative Commitment. Results describing the variance that the HRM practices factors explained in the three types of organizational commitment are presented below (see table $5)$. 
Table 5 presents the regression model accounting for most variation in PC Fulfilment by HRM practices. The following summary identifies the amount of variation:

The (Equal Employment Opportunity) factor explained the biggest variation (47\%) of the variation in employees' PC Fulfilment. Edgar and Geare (2005) suggested that greater use of equal employment opportunities would make employees more committed to an organization. The authors added that good and safe working conditions lead to higher organizational commitment among employees.

Rewards and Information Sharing both explained the second largest variation (43\%). Benefits explained (40\%) and Staffing explained (21\%) of the variation in employees PC Fulfilment. Performance Appraisal explained (13\%) and the lowest variation (8\%) in employee PC Fulfilment was explained by Training (see table 5).

Table 5 presents the regression model accounting for most variation in Organizational Commitment types by PC Fulfilment as well. The (PCFul) factor explained $9 \%$ of the variation in employees' Affective Commitment scores and explained $19 \%$ of the variation in employees' Normative Commitment scores, but explained some (7\%) of the variation in the employees' Continuance Commitment.

Table 5. Regression Model Accounting for Most Variations by Individual Factors of HRM Practices

\begin{tabular}{lllll}
\hline Factors & PCFul & $\begin{array}{l}\text { Affective } \\
\text { Commitment }\end{array}$ & $\begin{array}{l}\text { Normative } \\
\text { Commitment }\end{array}$ & $\begin{array}{l}\text { Continuance } \\
\text { Commitment }\end{array}$ \\
\hline Training & .083 & .092 & .086 & .023 \\
Performance Appraisal & .127 & .056 & .040 & .003 \\
Staffing & .208 & .104 & .061 & .021 \\
Rewards & .434 & .124 & .258 & .091 \\
Benefits & .404 & .101 & .148 & .047 \\
Working Conditions & .342 & .102 & .118 & .055 \\
Equal Employment Opportunity & .472 & .073 & .106 & .047 \\
Information Sharing & .431 & .127 & .128 & .069 \\
PCFul & - & .089 & .190 & .070 \\
\hline
\end{tabular}

* Significant at (0.05)

\section{Discussion and Conclusions}

Overall, the respondents' answers reveal that HRM practices were a positive, valued experience for them and had a positive impact on OC.

Hypothesis 1: HRM practices will be positively related to PC Fulfilment.

The hypothesis was supported in this study. A direct relationship between HRM practices and PC Fulfilment was found in this study. The findings suggest that greater use of HRM practices would lead to the fulfilment of employee psychological contracts. Thus, HRM practices emerge as a significant predictor of PC Fulfillment. Studies by Rousseau and Wade-Benzoni (1994) and Rousseau and Greller (1994) proposed that HRM practices make employees understand the terms of their employment, and hence act as message senders shaping the terms of the psychological contracts. Therefore, Rousseau and Greller (1994) proposed that greater use of HR would lead to the fulfilment of employee psychological contracts.

Lucero and Allen (1994) proposed ways of reducing conflict between worker expectations and employer practices and proposed benefits as the critical factor that would lead to the fulfilment of employee psychological contracts. However, the results of their study do not support the proposition.

Hypothesis 2: PC fulfilment will be positively related to $O C$.

The hypothesis was supported in this study. The goal was to examine the mediating effect of PCs on the relationship between HRM practices and OC. A direct relationship between PC Fulfillment and OC was found in this study. Based on their PCs, employees tend to hold beliefs regarding the inducements the organization is obligated to provide and to what extent the organization has actually fulfilled their obligations (Robinson et al., 
1994). When employees believe that the organization has fulfilled their obligations, they become more committed to the organization (Coyle-Shapiro \& Kessler, 2000).

\section{Hypothesis 3: HRM practices will be positively related to OC.}

The hypothesis was supported by the current data. The findings suggest that greater use of HRM practice effectiveness would make the employees more committed to the organization. The finding is consistent with studies by Chang (2005) and Edgar and Geare (2005), which found a significant effect of HRM practices on OC. Chang's (2005) study of the influence of employees' overall perception about the organization's HRM practices on OC suggested that a greater use of HRM practices would make the employees more committed to the organization.

According to this study's finding, when the hotel provides effective HRM Practices, employees believe that the organization cares about them and is committed to them. When employees believe that the organization supports them by providing good HRM practices, they reciprocate by being more committed to the organization. The findings are important for the industry and practitioners and they need to focus more on significant HRM practices. However, a significant positive relationship was found between HRM practices and PC, between PC Fulfilment and OC and a significant positive relationship was found between HRM practices and OC. It was anticipated that HRM practices would have a significant influence on PC, which would then have a significant influence on OC, and which, in turn, will conclude that HRM practices have a significant influence on OC.

The results of the study proposed that human resources management (HRM) practices are vital factors of organizational contracts (OC). The findings are consistent with Edgar and Geare's (2005) study, which suggests that HR managers need to conduct regular attitudinal surveys to assess employee reactions to current HRM practices and attempt to determine what is working and what is not. The Training factor explained the lowest variation (8\%) of the variation in employees PC. Employees perceive training as a support from the organization, and this belief makes them more committed to the organization (Bartlett, 2001). A significant positive relationship between training and OC was reported by Bartlett (2001) and the findings suggested that greater use of training will make employees more committed to the organization. The Performance Appraisal factor explained the second lowest variation (13\%) of the variation in employees' PC and the lowest variation (6\%) in Affective Commitment. Chang (2005) included performance appraisal as one of the HRM practices in the commitment HRM bundle, and the findings suggested that greater use of HRM practices would make employees more committed to their organization.

Information Sharing explained the most variation (13\%) in Affective Commitment and explained (13\%) of the variation in Normative Commitment.

Data collected in this research study show that the mean of HRM practice scores, PC Fulfilment and OC in general, are perceived to be high, but can be improved. Some HRM practices, Rewards, Benefits, Information Sharing and Equal Employment Opportunity, emerged as significant predictors of PC and OC. A study by Landau and Hammer (1986) showed that employees who perceived opportunities of advancement were more committed to their organizations. Similarly, a study by Coyle-Shapiro et al. (2002) showed the positive impact of profit sharing on OC. Arthur (1994) showed the impact of wages and bonus on organization performance.

In the HR scale, the statement "My employer asks my opinions about how I can improve my job" (3.66) received the weakest ratings and the statement (My employer encourages employee participation in benefits decision making) (3.73) received one of the weakest ratings. In nine studies involving 2,734 persons, Dunham, Grube, and Castaneda (1994) examined how participatory management and supervisory feedback influenced employee levels of affective, continuance and normative commitment. The researchers found that when supervisors provided feedback about performance and allowed employees to participate in decision-making, employee levels of affective commitment were stronger than both continuance and normative. That is, employees indicated staying with the organization was more related to wanting to, rather than needing to or feeling they ought to.

\section{Recommendations}

1). Based on the study data and current research, the study indicates that department heads should consider concentrating on their leadership behaviors to increase job commitment. Gonzalez and Garazo (2006) suggest that hotel managers should put great emphasis on front line employees to stimulate job satisfaction and organizational citizenship behavior. When employees believe that their supervisors support them (perceived supervisor support) the result is increased performance, commitment to the organization and job satisfaction (Eisenberger et al., 2002). 
2). Training and development affect job satisfaction and organizational commitment (Lam \& Zhang, 2003; Lowry et al., 2002; Pratten, 2003; Smith, 2002; Taylor et al., 2001). A well-designed staff development program can assist in raising their morale and organizational commitment, as well as contributing to continuous improvements (Chong \& Rundus, 2004; Feng et al., 2006; Hirtz et al., 2007). Hotels should continue to offer additional training and related workshops/seminars on the components of their HR programs and their impact on performance indicators, quality, organizational commitment and citizenship and job satisfaction to assist department heads in developing a higher level of competence

3). Researchers examining the effects of participative management strategies based on empowerment philosophies in the hotel industry argue that such strategies will increase employee involvement, and this, in turn, will lead to more favourable job-related outcomes such as organizational commitment (Gray and Ligouri, 1994; Parsons, 1995). When employees believe that their supervisors support them (perceived supervisor support) the result is increased performance, commitment to the organization and job satisfaction (Eisenberger et al., 2002).

4). HR departments in hotels should develop programs for performance-related pay and review the pay increases periodically and develop social activities, assure high levels of equal pay, cooperation and trust among employees to reduce job stress and increase the employees perception of PC fulfillment and OC. Prior studies proposed that performance rewards like promotion, profit sharing, benefits and opportunities results in positive attitudes and behaviour and positively impact OC (Landau \& Hammer, 1986; Arthur, 1994; Coyle-Shapiro et al., 2002).

5). Hotels should improve working conditions to increase job satisfaction. Ghiselli et al. (2001) indicated that salaries, benefit packages, working hours, family and quality of life were the reasons for satisfaction and/or dissatisfaction. Many researchers have discussed job satisfaction as an antecedent of organizational commitment (Chen, 2006; Laschinger et al., 2002; Feinstein \& Vondrasek, 2001; Gaertner, 1999). Aksu and Aktas (2005) investigated job satisfaction of middle and upper level managers in five-star hotels. The findings indicate that the working conditions should be improved in order to increase general job satisfaction of the managers since promotion, morale conditions, financial rewards, compensation, fringe benefits and working hours are important factors that affect the managers' satisfaction and, in turn, will affect the OC. Jernigan et al. (2002) examined the role that specific aspects of work satisfaction serve as predictors of organizational commitment type. Hotels should improve the working conditions to increase the job commitment. As noted earlier, Edgar and Geare (2005) indicated that good and safe working conditions lead to higher organizational commitment among employees.

More research in this part is needed and can help specialists and academicians to decide which HRM practices have a greater effect on organizational contract (OC). This study affords a foundation for future studies with different HRM practices, industries and populations. Overall, this study provides an approach for academicians and practitioners to find the best HRM practices that would work for hotels to enhance their organizational commitment.

\section{References}

Aksu, A., \& Aktas, A. (2005). Job satisfaction of managers in tourism: Cases in the Antalya region of Turkey. Managerial Auditing Journal, 20(5), 479-488. https://doi.org/10.1108/02686900510598830

Allen, N. J., \& Meyer, J. P. (1990). The measurement and antecedents of affective, continuance and normative commitment to the organization. Journal of Occupational Psychology, 63(1), 1-18. https://doi.org/10.1111/j.2044-8325.1990.tb00506.x

Angle, H. \& Perry, J. (1981). An empirical assessment of organizational commitment and organizational effectiveness. Administrative Science Quarterly, 26, 1-14. https://doi.org/10.2307/2392596

Atkinson, H., \& Brander Brown, J. (2001). Rethinking performance measures: Assessing progress in UK hotels. International Journal of Contemporary Hospitality Management, 13(3), 128-135. https://doi.org/10.1108/09596110110388918

Balkin, D. B., \& Gomez-Mejia, L. R. (1990). Matching compensation and organizational strategies. Strategic Management Journal, 11(2), 153-169. https://doi.org/10.1002/smj.4250110207

Balzer, W. K., Kihm, J. A., Smith, P. C., Irwin, J. L., Bachiochi, P. D., Robie, C., Sinar, E. F., \& Parra, L. F. (2000). Users' manual for the Job Descriptive Index (JDI; 1997 version) and the Job in General scales. In J. M. Stanton and C. D. Crossley (Eds.), Electronic resources for the JDI and JIG. Bowling Green, OH: Bowling Green State University. 
Bartlett, K. R. (2001). The relationship between training and organizational commitment: A study in the health care field. Human Resource Development Quarterly, 12(4), 335-352. https://doi.org/10.1002/hrdq.1001

Bateman, T. S., \& Strasser, S. (1984). A longitudinal analysis of the antecedents of organizational commitment. Academy of Management Journal, 27, 95-112. https://doi.org/10.2307/255959

Batt, R. (2002). Managing customer services: Human resource practices, quit rates, and sales growth. Academy of Management Journal, 45, 587-597. https://doi.org/10.2307/3069383

Chang, E. (2005). Employee's overall perception of HRM effectiveness. Human Relations, 58(4), 523-544. https://doi.org/10.1177/0018726705055037

Chang, P., \& Chen, W. (2002). The effect of human resource management practices on firm performance: Empirical evidence from high-tech firms in Taiwan. International Journal of Management, 19(4), 622-631.

Chen, C. F. (2006). Short report: Job satisfaction, organizational commitment, and flight attendants' turnover intentions: A note. Journal of Air Transport Management, 12, 274-276. https://doi.org/10.1016/j.jairtraman.2006.05.001

Chong, V., \& Rundus, M. (2004). Total quality management, market competition and organizational performance. The British Accounting Review, 36, 155-172. https://doi.org/10.1016/j.bar.2003.10.006

Cohen, A. (1996). On the discriminant validity of the Meyer and Allen measure of organizational commitment: How does it fit with the work commitment construct? Educational and Psychological Measurement, 56, 494-503. https://doi.org/10.1177/0013164496056003011

Coomber, B., \& Barriball K. L. (2006). Impact of job satisfaction components on intent to leave and turnover for hospital-based nurses: A review of the research literature. International Journal of Nursing Studies, 44(2), 297-314. https://doi.org/10.1016/j.ijnurstu.2006.02.004

Coyle-Shapiro, J. A. M., \& Conway, N. (2005). Perceived organizational support and employee diligence, commitment, and innovation. Journal of Applied Psychology, 90, 774-781. https://doi.org/10.1037/0021-9010.90.4.774

Coyle-Shapiro, J. A. M., \& Kessler, I. (2000). Consequences of the psychological contract for the employment relationship: A large scale survey. Journal of Management Studies, 37, 903-930. https://doi.org/10.1111/1467-6486.00210

Coyle-Shapiro, J., Morrow, P. C., Richardson, R., \& Dunn, S. R. (2002). Using profit-sharing to enhance employee attitudes: A longitudinal examination of the effects on trust and commitment. Human Resource Management, 4l(4), 423-438. https://doi.org/10.1002/hrm.10052

Deery, M. A., \& Shaw, R. N. (1999). An investigation of the relationship between employee turnover and organisational culture. Journal of Hospitality andTourism Research, 23(4), 387-400.

Dunham, R., Grube, J., \& Castaneda, M. (1994). Organizational commitment: The utility of an integrative definition. Journal of Applied Psychology, 79, 370-380. https://doi.org/10.1037/0021-9010.79.3.370

Edgar, F., \& Geare, A. (2005). HRM practice and employee attitudes: Different measures different results. Personnel Review, 34(5), 534-549. https://doi.org/10.1108/00483480510612503

Eisenberger, R., Stinglhamer, F., Vandenberghe, C., Sucharski, I. L., \& Rhoades, L. (2002). Perceived supervisor support: Contributions to perceived organizational support and employee retention. Journal of Applied Psychology, 87(3), 565. https://doi.org/10.1037/0021-9010.87.3.565

Eisenberger, R., Fasolo, P. \& LaMastro, V. D. (1990). Perceived organizational support and employee diligence, commitment, and innovation. Journal of Applied Psychology, 75, 51-59. https://doi.org/10.1037/0021-9010.75.1.51

Erdogan, B. (2002). Antecedents and consequences of justice perceptions in performance appraisals, Human Resource Management Review, (12), 555-578. https://doi.org/10.1016/S1053-4822(02)00070-0

Feinstein, A. H. \& Vondrasek, D. (2001). A study of relationships between job satisfaction and organizational commitment among restaurant employees. Journal of Hospitality, Tourism, and Leisure Science, available at: http://hotel.unlv.edu/pdf/jobSatisfaction.pdf

Feng, J., Prajogo, D., Tan, K., Sohal, A. (2006). The impact of TQM practices on performance: A comparative study between Australian and Singaporean organizations. European Journal of Management, 9(3), 269-278. https://doi.org/10.1108/14601060610678149 
Furnham, A., Petrides, K. V., Jackson, C. J., \& Cotter, T. (2002). Do personality factors predict job satisfaction? Personality and Individual Differences, 33, 1325-1342. https://doi.org/10.1016/S0191-8869(02)00016-8

Gaertner, S. (1999). Structural determinants of job satisfaction and organizational commitment on turnover models. Human Resource Management Review, 9(4), 479-493. https://doi.org/10.1016/S1053-4822(99)00030-3

Ghiselli, R .F., La Lopa, J., \& Bai, B. (2001). Job satisfaction, life satisfaction and turnover intend among food service managers. Cornell Hotel and Restaurant Administration Quarterly, April, 28-37.

Gonzalez, J.V., and Garazo, T.G. (2006). Structural relationships netween organizational service orientation, contact employee job satisfaction and citizenship behavior. International Journal of Service Industry Management, 17(1), 23-50. https://doi.org/10.1108/09564230610651561

Gray, W., \& Ligouri, S. (1994). Hotel and Motel Management and Operation s. Prentice-Hall, New York.

Guzzo, R. A., \& Noonan, K. A. (1994). Human resource practices as communications and the psychological contract. Human Resource Management, 33(3), 447-462. https://doi.org/10.1002/hrm.3930330311

Hackett, R., Bycio, P., \& Hausdorf, P. (1994). Further assessments of Meyer and Allen's (1991) three-component model of organizational commitment. Journal of Applied Psychology, 79, 15-23. https://doi.org/10.1037/0021-9010.79.1.15

Hardman, T. M. (1996). A study of job satisfaction of female public school administrators in West Virginia. Unpublished doctoral dissertation, West Virginia University, Morgantown, WV.

Harris, P., \& Mongiello, M. (2001). Key performance indicators in European hotel properties: general managers' choice and company profiles. International Journal of Contemporary Hospitality Management, 13(3), 120-127. https://doi.org/10.1108/09596110110388909

Hilgerman, R. (1998). Communication satisfaction, goal setting, job satisfaction, concertive control, and effectiveness in self-managed teams. Dissertation Abstracts International, 59, 1661.

Hirtz, P., Murray, S., \& Riordan, C. (2007). The effects of leadership on quality. Engineering Management Journal, 19(1), 22-27. https://doi.org/10.1080/10429247.2007.11431718

Hoque, K. (1999). Human resource management and performance in the UK hotel industry. British Journal of Industrial Relations, 37(3), 419-443. https://doi.org/10.1111/1467-8543.00135

Huselid, M. A. (1995). The impact of human resource management practices on turnover, productivity, and corporate financial performance. Academy of Management Journal, 38, 635-672. https://doi.org/10.2307/256741

Iverson, R. D., \& Deery, M. (1997). Turnover culture in the hospitality industry. Human Resource Management Journal, 7(4), 71-82. https://doi.org/10.1111/j.1748-8583.1997.tb00290.x

Jernigan, I. E., Beggs, J. M., \& Kohut, G. F. (2002). Dimensions of work satisfaction as predictors of commitment type. Journal of Managerial Psychology, 17(7), 564-579. https://doi.org/10.1108/02683940210444030

Jones, P. (1988). Quality, capacity and productivity in service industries. International Journal of Hospitality Management, 7(2), 104-112. https://doi.org/10.1016/0278-4319(88)90031-X

Jones, P. (1990). Managing foodservice productivity in the long term: strategy, structure and performance. International Journal of Service Industry Management, 9(2), 143-154. https://doi.org/10.1016/0278-4319(90)90009-M

Kim, W .G., Leong, J. K., \& Lee, Y. (2005). Effect of service orientation on job satisfaction, organizational commitment, and intention of leaving in a casual dining chain restaurant. Hospitality Management, 24, 171-193. https://doi.org/10.1016/j.ijhm.2004.05.004

Kinicki, A. J., Carson, K. P., \& Bohlander, G. W. (1992). Relationship between an organization's actual human resource efforts and employee attitudes. Group and Organizational Management, 17, 135-152. https://doi.org/10.1177/1059601192172003

LaLopa, J. M. (1997). Commitment and turnover in resort jobs. Hospitality Research Journal, 21(2), 11-26. https://doi.org/10.1177/109634809702100202

Lam, T., \& Zhang, H.Q. (2003). Job satisfaction and organizational commitment in the Hong Kong fast food industry. International Journal of Contemporary Hospitality Management, 15(4), 214-29. https://doi.org/10.1108/09596110310475667 
Landau, J., \& Hammer, T. H. (1986). Clerical employees' perceptions of intraorganizational career opportunities. Academy of Management Journal, 29, 385-404. https://doi.org/10.2307/256194

Lau, C. M., \& Chong, J.(2002). The effects of budget emphasis, participation and organizational commitment on job satisfaction: Evidence from the financial services sector. Advances in Accounting Behavioral Research, 5, 183-211. https://doi.org/10.1016/S1474-7979(02)05042-1

Lashley, C., \& Best, W. (2002), Employee induction in licensed retail organizations. International Journal of Contemporary Hospitality Management, 14(1), 6-13. https://doi.org/10.1108/09596110210415060

Lee, K. (1992). A study of affective, continuance, and normative commitment to the organization, Unpublished master's thesis, Sung Kyun Kwan University, Seoul, Korea.

Loui, K. (1995). Understanding employee commitment in the public organization: A study of the juvenile detention center. International Journal of Public Administration, 18(8), 1269-1295. https://doi.org/10.1080/01900699508525052

Lowry, D., Simon, A., \& Kimberley, N. (2002). Toward improved employment relations practices of casual employees in the New South Wales registered clubs industry. Human Resources Development Quarterly, 13(1), 53-70. https://doi.org/10.1002/hrdq.1013

Lucero, M. A., \& Allen, R. E. (1994). Employee benefits: A growing source of psychological contract violations. Human Resource Management, 33(3), 425-446. https://doi.org/10.1002/hrm.3930330310

MacDuffie, J. (1995). Human resource bundles and manufacturing performance: organizational logic and flexible production systems in the world auto industry. Industrial and Labour Relations Review, 48(2), 197-221. https://doi.org/10.1177/001979399504800201

Mathieu, J. E., \& Zajac, D. M. (1990). A review and meta-analysis of the antecedents, correlates, and consequences of organisational commitment. Psychological Bulletin $n_{2}$ 108(2), 171-194. https://doi.org/10.1037/0033-2909.108.2.171

Maxwell, G., \& Steele, G. (2003). Organizational commitment: a study of managers inHotels. International $\begin{array}{llll}\text { Journal of Contemporary Hospitality } & \text { Management, 15(7), }\end{array}$ https://doi.org/10.1108/09596110310496006

McCaughey, D., \& Bruning, N. S. (2005). Enhancing opportunities for expatriate job satisfaction: HR strategies for foreign assignment success. Human Resource Planning, 28, 21-29.

McGunnigle, P. J., \& Jameson, S. M. (2000). HRM in UK hotels: a focus on commitment. Employee Relations, 22(4), 403-422. https://doi.org/10.1108/01425450010340380

McShane, S. L., \& Steen, S. (2009). Canadian organizational behaviour (7th ed.). Toronto: McGraw-Hill.

Meyer, J. P., \& Allen, N. J. (1991). A three-component conceptualization of organizational Commitment. Human Resource Management Review, 1, 61-89. https://doi.org/10.1016/1053-4822(91)90011-Z

Meyer, J. P., Allen, N. J., \& Smith, C. A. (1993). Commitment to organizations and occupations: Extension and test of a three-component conceptualization. Journal of Applied Psychology, 78, 538-551. https://doi.org/10.1037/0021-9010.78.4.538

Meyer, J. P., \& Allen, N. J. (1997). Commitment in the Work Place: Theory, Research and Application. Thousand Oaks, CA: Sage Publications.

Meyer, J. P., \& Smith, C. A. (2000). HRM practices and organizational commitment: Test of a mediation model. $\begin{array}{lllll}\text { Canadian Journal of } & \text { Administrative }\end{array}$ https://doi.org/10.1111/j.1936-4490.2000.tb00231.x

Mohrman, A. M., Cooke, R. S., Mohrman, S. A., Duncan, R. B. \& Zaltman, G. (1977). An assessment of a structural task approach to organizational development in a school system. Washington, DC: National Institute of Education.

Molinari D. L., Monserud, M. A. (2008). Rural nurse job satisfaction. Rural and Remote Health. Rural and Remote Health, 8(4), pp. 1055 (Online).

Namasivayam, K. (2005). Connecting organizational human resource practices to consumer satisfaction. International Journal of Service Industry Management, 16, 253-270. https://doi.org/10.1108/09564230510601396 
Parsons, G., 1995. Empowering employees—back to the future at Novotel. Managing Service Quality, 5(4), 16-21. https://doi.org/10.1108/09604529510796458

Pathak, R. D., Budhwar, P. S., Singh, V. \& Hannas, P. (2005). Best HRM practices and employee's psychological outcomes: A study of shipping companies in Cyprus. South Asian Journal of Management, 12(4), 7-24.

Powers, T., \& Barrows, C. (1999). Introduction to Management in the Hospitality Industry. Wiley, New York.

Pratten, J. D. (2003). The training and retention of chefs. International Journal of Contemporary Hospitality Management, 15(4), 237-42. https://doi.org/10.1108/09596110310475702

Ramsay, H., Scholarios, D., \& Harley, B. (2000). Employees and high performance work systems: Testing inside the black box. British Journal of Industrial Relations, 38(4), 501-531. https://doi.org/10.1111/1467-8543.00178

Randall, D. M. (1990). The consequences of organisational commitment: Methodological investigation. Journal of Organisational Behavior, 11, 361-378. https://doi.org/10.1002/job.4030110504

Roberts, W. (2001). It takes more than a carrot and a stick. New York: Andres McMeel.

Robinson, S. L., Kraatz, M. S., \& Rousseau, D. M. (1994). Changing the obligations and the psychological contract. Academy of Management Journal, 37, 437-452. https://doi.org/10.2307/256773

Rousseau, D. M. (1989). Psychological and implied contracts in organizations. Employee Responsibilities and Rights Journal, 2, 121-139. https://doi.org/10.1007/BF01384942

Rousseau, D. M., \& Greller, M. M. (1994). Human resource practices: Administrative contract makers. Human Resource Management, 33(3), 385-401. https://doi.org/10.1002/hrm.3930330308

Rousseau, D. M., \& Wade-Benzoni, K. A. (1994). Linking strategy and human resource practices: How employee and customer contracts are created. Human Resource Management, 33(3), 463-489. https://doi.org/10.1002/hrm.3930330312

Saudi Chambers, Publications \& Reports, (Riyadh chambers of commerce \& Industry Publications \& Reports). (2009). Retrieved on April, 2010 from: http:// www.riyadchambers.com/newsarchive.php http:// www.saudichambers.org.sa

Saudi Tourism Information and Research Centre, Publications \& Reports. (2009). Retrieved on March, 2010 from: http:// www.mas.gov.sa

Smith, E. (2002). Training equals staff loyalty at Paramount. Training and Management Development Methods, 16(1), 401-3.

Spence Laschinger, H.K., Finegan, J., \& Shamian, J. (2002). The impact of workplace empowerment, organizational trust on staff nurses' work satisfaction and organizational commitment. Advances in Health Care Management, 3, 59-85. https://doi.org/10.1016/S1474-8231(02)03006-9

Tansky, J. W., \& Cohen, D. J. (2001). The relationship between organizational support, employee development, and organizational commitment: An empirical study. Human Resource Development Quarterly, 12(3), 285-300. https://doi.org/10.1002/hrdq.15

Taylor, R., Davies, D., \& Savery, L. (2001). The role of appraisal and training in reducing staff turnover in the Western Australian accommodation industry. Management Research News, 24(10/11), 56-7.

Townsend, K. (2004). Management culture and employee resistance: Investigating the management of leisure service employees. Managing Leisure, 9, 47-58. https://doi.org/10.1080/1360671042000194952

Vardi, Y, Wiener, Y., \& Popper, M. (1989). The value content of organizational mission as a factor in the commitment of members. Psychological Reports, 65, 27-34. https://doi.org/10.2466/pr0.1989.65.1.27

Whitener, E. \& Walz, P. (1993). Exchange theory determinants of affective and continuance commitment and turnover. Journal of Vocational Behavior, 42, 265-281. https://doi.org/10.1006/jvbe.1993.1019

Wildes, V. (2005). Stigma in food service work: How it affects restaurant servers' intention to stay in the business or recommend a job to another. Tourism and Hospitality Research, 5(3), 213-33. https://doi.org/10.1057/palgrave.thr.6040022

Wilkins, H., Meriless, B., \& Herington, C. (2007). Towards an understanding of total service quality in hotels. International Journal of Hospitality Management, 26(4), 840-853. https://doi.org/10.1016/j.ijhm.2006.07.006 
Woods, R. H., Sciarini, M., \& Breiter, D. (1998). Performance appraisal in hotels. Cornell Hotel and Restaurant Administration Quarterly, 39, 25-29. https://doi.org/10.1177/001088049803900205

Xenikou, A., \& Simosi, M. (2006). Organizational culture and transformational leadership as predictors of business unit performance. Journal of Managerial Psychology, 21(6), 566-579. https://doi.org/10.1108/02683940610684409

\section{Copyrights}

Copyright for this article is retained by the author(s), with first publication rights granted to the journal.

This is an open-access article distributed under the terms and conditions of the Creative Commons Attribution license (http://creativecommons.org/licenses/by/4.0/). 